\title{
Bilateral Laparoscopic Gonadectomy in a Patient With Complete Androgen Insensitivity Syndrome and Bilateral Sertoli-Leydig Cell Tumor: A Case Report and Brief Review of the Literature
}

\author{
Mohammad Asl Zare ${ }^{1}$; Mahmood Reza Kalantari ${ }^{2}$; Amir Abbas Asadpour ${ }^{1}$; Ali Kamalati ${ }^{3,{ }^{*}}$ \\ ${ }^{1}$ Department of Urology, Faculty of Medicine, Mashhad University of Medical Sciences, Mashhad, IR Iran \\ 2 Department of Pathology, Faculty of Medicine, Mashhad University of Medical Sciences, Mashhad, IR Iran \\ ${ }^{3}$ Department of Urology, Faculty of Medicine, Kerman University of Medical Sciences, Kerman, IR Iran \\ ${ }^{*}$ Corresponding author: Ali Kamalati, Department of Urology, Faculty of Medicine, Kerman University of Medical Sciences, Kerman, IR Iran. Tel: +98-3412235011, Fax: +98-3412260100, \\ E-mail:ali.kamalati@yahoo.com
}

Received: October 6, 2013; Revised: December 2, 2013; Accepted: January 11, 2014

\begin{abstract}
Introduction: Complete androgen insensitivity syndrome (previously called testicular feminization) is specified by a $46 \mathrm{XY}$ karyotype and negative sex chromatin, bilateral undescended testes, female genitalia appearance, and lack of mullerian derivatives.

Case Presentation: A 28-year-old woman with complete (severe) androgen resistance underwent prophylactic laparoscopic bilateral gonadectomy because of the eventually increased risk of gonadal malignancy. Although the gonads appeared grossly normal, microscopic examination revealed bilateral well differentiated sertoli-leydig cell tumor(SLCT).

Discussion: Our Medline search revealed that this is the first reported case of bilateral sertoli-leydig cell tumor (SLCT) in androgen insensitivity syndrome.
\end{abstract}

Keywords:Androgen-Insensitivity Syndrome; Sertoli-Leydig Cell Tumor; Laparoscopy

\section{Introduction}

Complete androgen insensitivity syndrome (AIS - previously called testicular feminization) is specified by a 46 $\mathrm{XY}$ karyotype and negative sex chromatin, bilateral undescended testes, female genitalia appearance, and lack of mullerian derivatives. The patient is phenotypically female without uterus and a blind shortened vagina (1). This syndrome is often diagnosed during puberty while the patient is being evaluated due to primary amenorrhea (2).

Complete AIS is accompanied with abnormal testicular development and increase risk of germ cell malignancy beginning after puberty. For these reason, prophylactic gonadectomy is advised in the postpubertal period to avoid potential malignant transformation (2). We present the first documented case of bilateral sertoli-leydig cell tumor (SLCT) in a patient with complete (severe) AIS.

\section{Case Presentation}

A 28-year-old nulligravida was referred for consultation and laparoscopic bilateral gonadectomy after diagnosis of complete androgen resistance. The patient complained of primary amenorrhea but she did not have inguinal hernia or labial mass. She had female external genitalia. In the physical examination, development of her breasts was normal (tanner stage IV), but axillary hair was scarce (tanner stage III). Abdominal examination was normal. No inguinal or labial mass was palpated. In gynaecological examination, the vulva and perineum appeared normal. She had a blind-ending vaginal pouch of approximately $6 \mathrm{~cm}$ depth and the cervix was invisible. No adnexal masses were palpated.

In pelvic ultrasonography, the uterus was absent and an ovoid heterogenous mass $(38 \times 23 \mathrm{~mm}$ in size $)$ with a 13 $\mathrm{mm}$ nodule in the right pelvic sidewall had been reported. Abdominal ultrasonography did not reveal any paraaortic lymphadenopathy. Pelvic ultrasonography failed to identify the left gonad. Blood tests for hormones showed Follicle-stimulating hormone and luteinizing hormone levels were $7 \mathrm{mIU} / \mathrm{mL}$ and $32 \mathrm{mIU} / \mathrm{mL}$, respectively and serum testosterone was $3.1 \mathrm{ng} / \mathrm{mL}$, all of which were within the normal ranges. Cytogenetic analysis showed a male karyotype (46, XY).

The patient underwent laparoscopic gonadectomy under general anesthesia in the supine position. Visualization of pelvic contents revealed absence of uterus and fallopian tubes. There was not any evidence of abdominal or pelvic lymphadenopathy. Laparoscopic study demonstrated a $4 \times 2.5 \mathrm{~cm}$ gray-purple colored ovoid mass with 1 $\mathrm{cm}$ cystic mass near the right internal inguinal ring. The left gonad $(4.5 \times 2 \mathrm{~cm})$ was hidden behind the bowels in

Implication for health policy/practice/research/medical education:

We present the first documented case of bilateral benign sertoli-leydig cell tumor (SLCT) in androgen insensitivity syndrome.

Copyright (c) 2014, Nephrology and Urology Research Center; Published by Kowsar Corp. This is an open-access article distributed under the terms of the Creative Commons Attribution License, which permits unrestricted use, distribution, and reproduction in any medium, provided the original work is properly cited. 

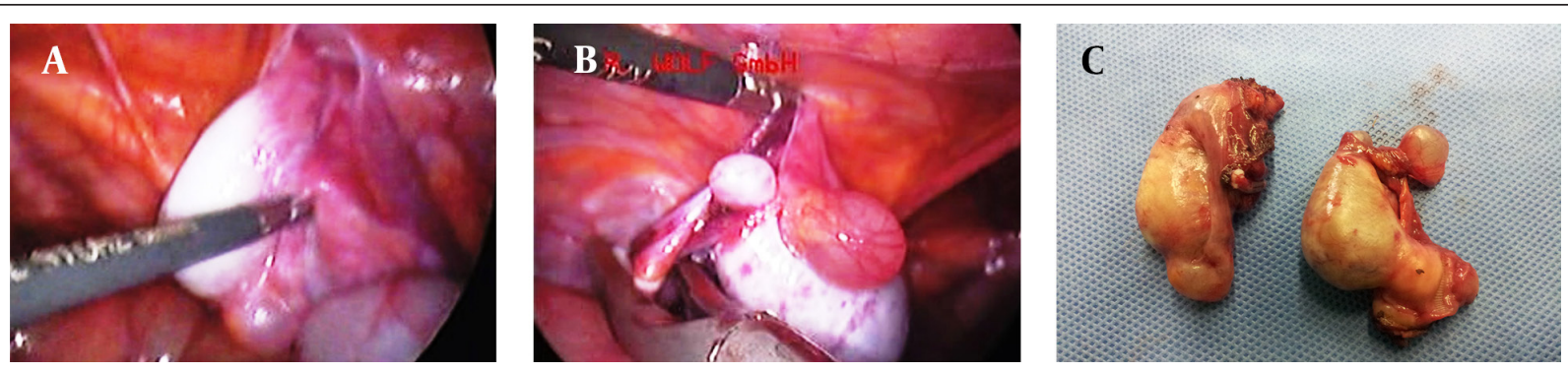

Figure 1. A. Laparoscopic View of the Left Gonad; B. The Right Gonad; C. Gross Image of the Removed Gonads
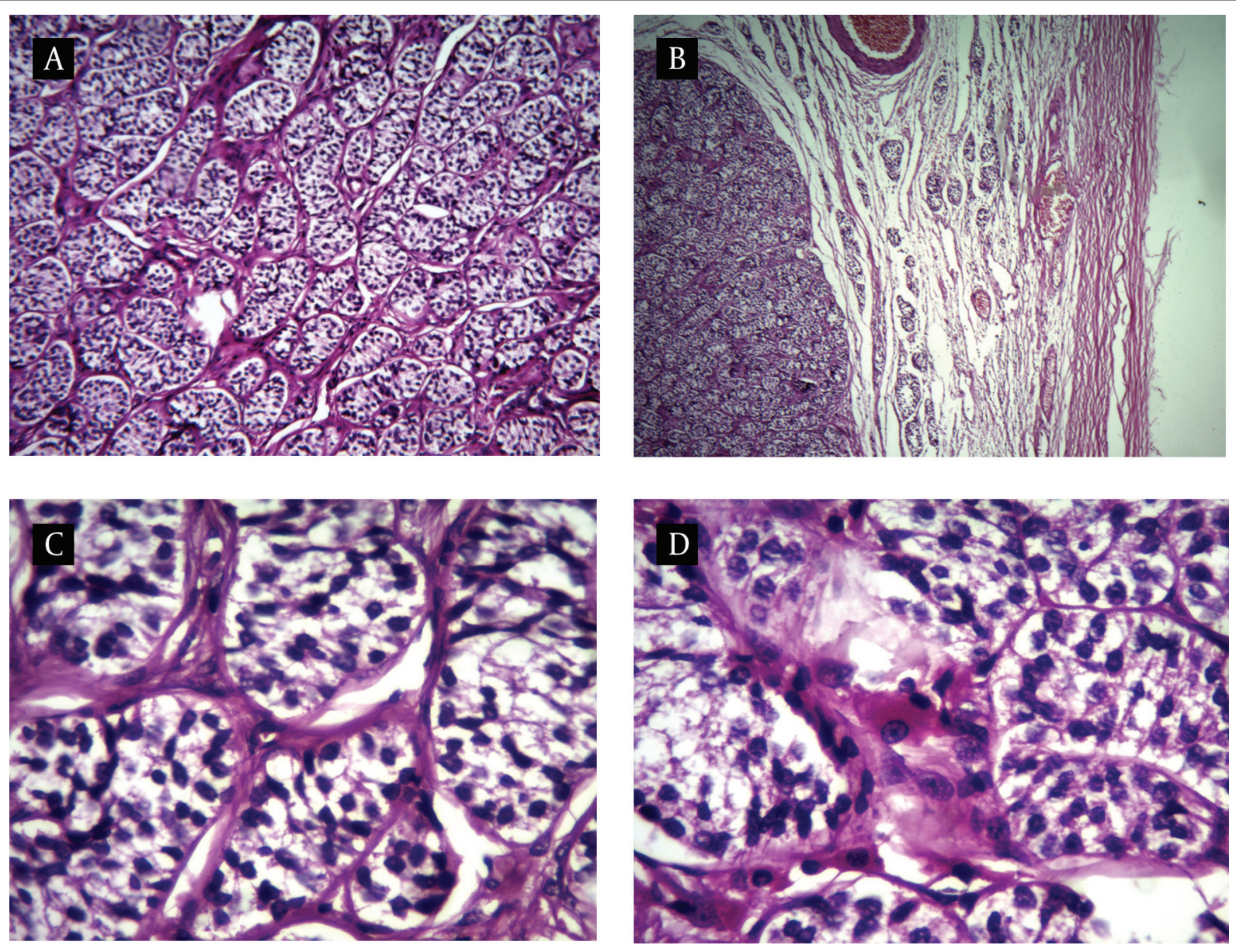

Figure 2. Well-differentiated Sertoli-Leydig Cell Tumor: A. The Tumor Is Well Circumscribed; B. Tumor Growth in Aluminal Tubular Pattern; C. Tumoral Cells Reveal Dark Round to Oval Nuclei and Clear Cytoplasm; D. Inervening Stroma Contain of Large Polygonal Cells Reminiscence to Leydig Cells.

the left pelvic sidewall. The gonad and the attached structure were retracted medially. The posterior peritoneum and gonadal vessels were incised after coagulation and ligation, and the gonads were removed from the pelvic sidewalls (Figure 1).

Macroscopically, the specimen consist of two ovoid gray mass which one of them contained two well-delineated, homogenous yellow-tan nodules measuring 1.5 and $1 \mathrm{~cm}$ on cut surface, respectively. Another mass on cut surface contained one $2.3 \mathrm{~cm}$ nodule similar to above description. Histopathological examination of the gonads in non-neoplastic region showed prepubertal immature tubules with lined sertoli cells. Microscopic examination of delineated nodules revealed a luminal-tubular pattern populated by monomorphus cells with dark round to oval nuclei reminiscence of immature sertoli cells. Intervening stroma was scant and focally contained clusters of polygonal cells with abundant eosinophilic or vacuolated 
Asl Zare M et al.

Table 1. Reported Cases of Sex Cord Stromal Tumors in Patients With Complete Androgen Insensitivity Syndrome

\begin{tabular}{|c|c|c|c|c|}
\hline Tumor Type & Age, $y$ & Tumor Size, cm & Localization & Reference \\
\hline Sertoli cell adenoma & 21 & $7.5 \times 3$ & right gonad & O'Connell et al. (17) \\
\hline Sertoli cell adenoma & 82 & $24 \times 19$ & left gonad & Damjanow et al. (18) \\
\hline Sertoli cell adenoma & 20 & $5 \times 2.5$ & left gonad & Ramaswamy et al. (19) \\
\hline Sertoli cell adenoma (10 cases) & $17-53$ & 0.5 to 14 & left gonad & Rutgers and Scully (13) \\
\hline $\begin{array}{l}\text { Large cell calcifying sertoli cell tumor / sex cord } \\
\text { tumor with annular tubules ( } 2 \text { caces) }\end{array}$ & 18 and 20 & 1 to 8 & left gonad & Rutgers and Scully (13) \\
\hline Sertoli cell tumor & 26 & $26 \times 17$ & bilateral & Wysocka et al. (14) \\
\hline Sertoli cell adenoma & 22 & 2 & left gonad & Ko et al. (20) \\
\hline $\begin{array}{l}\text { Sertoli cell tumor and adenocarcinoma of tunica } \\
\text { vaginalis testis }\end{array}$ & 72 & $35 \times 25$ & & Fleckenstein et al. (21) \\
\hline Sertoli cell adenoma and serous cyst & 30 & & bilateral & Baksu et al. (10) \\
\hline Malignant leydig cell tumor & 73 & $10.5 \times 9.5$ & left gonad & Iwamoto et al. (11) \\
\hline $\begin{array}{l}\text { Sertoli-leydig cell tumor and ureteral transitional } \\
\text { cell carcinoma }\end{array}$ & 57 & $2 \times 1.8$ & right gonad & Choi et al. (22) \\
\hline Sertoli cell adenoma & 53 & $14 \times 10 \times 10$ & left gonad & Scully et al. (23) \\
\hline Sertoli cell tumor & 60 & $\begin{array}{l}\text { large abdominal } \\
\text { tumor }\end{array}$ & & Knoke et al. (24) \\
\hline Sertoli cell adenoma & 67 & $15 \times 14 \times 10$ & left gonad & Lentz et al.(25) \\
\hline Sertoli cell adenoma & 81 & $16 \times 11 \times 6$ & left gonad & Detre and Bujdoso (26) \\
\hline $\begin{array}{l}\text { Large cell calcifying sertoli cell tumor/sex cord tu- } \\
\text { mor with annular tubules ( } 2 \text { cases) }\end{array}$ & 19 & $8 \times 8 \times 4.5$ & right gonad & Ramaswamy et al. (19) \\
\hline Sertoli-leydig cell tumor & & & & Jarzabec et al. (15) \\
\hline Sertoli-Leydig cell tumor & 29 & & left gonad & Ozulker et al. (16) \\
\hline Sertoli cell tumor and ITGCN & 15 & & $\begin{array}{l}\text { separate } \\
\text { gonads }\end{array}$ & Lin et al. (27) \\
\hline Sertoli-leydig cell tumor & 28 & $4 \times 2.5$ & Bilateral & present case \\
\hline
\end{tabular}

cytoplasm and round nucleus with prominent nucleoli. Mitotic activity was not prominent and necrosis was not seen (Figure 2). These findings were consistent with bilateral well differentiated sertoli-leydig cell tumor (SLCT). Our patient is being followed up regularly and she has no complain after a year.

\section{Discussion}

AIS is the most common type of male pseudohermafroditism characterized by absence of androgen receptor (AR) activity due to a mutation at Xq11-q12 localization on the androgen receptor gene (3-5). It is known as an Xlinked recessive disease, but up to $30 \%$ of mutations may be presented as sporadic de novo mutations (6). The incidence of this condition is 1 in 99,000 to 1 in 20,000 female births (7-9). These patients may be seen with a spectrum of phenotypic disorders that varies from pure female complete androgen insensitivity syndrome (CAIS), ambiguous genitalia partial androgen insensitivity (PAIS) and to phenotypically infertile male minimal androgen insensitivity form (MAIS) (2).

The complete form is 10 times more common than the incomplete form and the initial presentation is primary amenorrhea in adolescents with female phenotype, lack of pubic hair, or inguinal hernia containing testis and characterized by a 46 XY genotype and normal male androgen and gonadotropin value. Pelvic ultrasonography usually shows absence of mullerian derivates and vaginal examination reveals a blind-ending vagina without a cervix. Notably, on physical examination, all of these characteristics were present in our patient (2). In children or infants with a female phenotype, androgen insensitivity syndrome may present as inguinal hernia or mass and ambiguous genitalia. About $50 \%$ of patients with complete (severe) AIS have an inguinal hernia. Conversely, $1-2 \%$ of apparently female infants with inguinal hernia are diagnosed to have a $46 \mathrm{XY}$ karyotype and complete AIS. It may be found during workup for lower abdominal pain (10), abdominal mass (11), painful intercourse, or diagnosed incidentally on imaging investigations (12). The testes may be found in the abdomen, inguinal canal, or labia. Abnormalities of testicular development and risk of gonad malignancy increase after puberty.

Testis tumor developing risk is thought to be $3.6 \%$ by 
25 years and $33 \%$ by 50 years $(11,13)$. In a case series of 43 patients with AIS by Rutgers and Scully, 63\% hamartomas, 23\% sertoli cell adenomas and 9\% malignant tumors including two seminomas, one intratubular germ cell neoplasm with early stromal invasion and a malignant sex cord tumor were reported (13). We reviewed the previous articles on gonadal tumors in CAIS patients (Table 1). Most cases are unilateral sertoli adenoma or tumor. There are only two reported cases of bilateral gonadal tumors (10, 14). Also, there are only two cases of sertoli-leydig cell tumor which both were unilateral $(15,16)$.

In AIS pateints, prophylactic gonadectomy is advised in the postpubertal period due to avoid potential malignant transformation of the gonads $(2,28)$. Gonadectomy is recommended during the postpubertal period to help the development of feminization during puberty when the malignant changes in germ cells are relatively late and rare (13).

Sertoli-leydig cell tumor is a rare sex cord stromal neoplasm that account for less than $1 \%$ of ovarian tumors, occurring often in young adults $(29,30)$. It is also seldom developed among the patients with AIS and there is only two unilateral cases reported in the literature $(15,16)$. According to the amount of tubular differentiation of the sertoli cells and quantity of the primitive gonadal stroma, sertoli-leydig cell tumor is divided into well, intermediate and poorly differentiated types. Our patient had a well-differentiated form of SLCT, which is the most infrequently type seen with the good prognosis. To our knowledge, this is the first documented case report of bilateral benign sertoli-leydig cell tumor (SLCT) in androgen insensitivity syndrome.

\section{Acknowledgements}

There is no acknowledgment.

\section{Authors' Contribution}

Mohammad Asle Zare: project development, data collection. Mahmood Reza Kalantari: pathologic report. Amir Abbas Asadpour: project development, data collection. Ali Kamalati: project development, data collection, manuscript writing and editing.

\section{Financial Disclosure}

There is no financial or personal commitment with any individual or organization that may have determined the design and eventual outcome of this study.

\section{Funding/Support}

No funding source supported the preparation on this paper.

\section{References}

1. Sharma S, Balwan WK, Kumar P, Gupta S. Androgen insensitivity syndrome (testicular feminization). J Obstet Gynaecol India. 2012;62(2):199-201.

2. Galani A, Kitsiou-Tzeli S, Sofokleous C, Kanavakis E, Kalpini-Mavrou A. Androgen insensitivity syndrome: clinical features and molecular defects. Hormones (Athens). 2008;7(3):217-29.

3. Morris JM. The syndrome of testicular feminization in male pseudohermaphrodites. Am J Obstet Gynecol. 1953;65(6):1192-211.

4. Bowen P, Lee CS, Migeon CJ, Kaplan NM, Whalley PJ, McKusick VA, et al. Hereditary Male Pseudohermaphroditism with Hypogonadism, Hypospadias, and Gynecomastia: Reifenstein's Syndrome. Ann Intern Med. 1965;62:252-70.

5. Goldberg MB, Maxwell AF. Male pseudohermaphroditism proved by surgical exploration and microscopic examination; a case report with speculations concerning pathogenesis. J Clin Endocrinol Metab. 1948;8(5):367-79.

6. Hughes IA, Deeb A. Androgen resistance. Best Pract Res Clin Endocrinol Metab. 2006;20(4):577-98.

7. Grumbach MN. Disorders of sex differentiation. In: Larsen PR editor. Williams textbook of endocrinology. Philadelphia: Saunders; 2003. pp. 842-1002.

8. Bangsboll S, Qvist I, Lebech PE, Lewinsky M. Testicular feminization syndrome and associated gonadal tumors in Denmark. Acta Obstet Gynecol Scand. 1992;71(1):63-6.

9. Boehmer AL, Brinkmann O, Bruggenwirth H, van Assendelft C, Otten BJ, Verleun-Mooijman MC, et al. Genotype versus phenotype in families with androgen insensitivity syndrome.J Clin Endocrinol Metab. 2001;86(9):4151-60.

10. Baksu A, Kabukcuoglu F, Baksu B, Goker N. Bilateral sertoli cell adenoma and serous cyst in a patient with androgen insensitivity syndrome. Eur J Obstet Gynecol Reprod Biol. 2004;114(1):104-7.

11. Iwamoto I, Yanazume S, Fujino T, Yoshioka T, Douchi T. Leydig cell tumor in an elderly patient with complete androgen insensitivity syndrome. Gynecol Oncol. 2005;96(3):870-2.

12. Nguyen BD. PET imaging of Sertoli cell tumor in androgen insensitivity syndrome. Clin Nucl Med. 2003;28(9):743-5.

13. Rutgers JL, Scully RE. The androgen insensitivity syndrome (testicular feminization): a clinicopathologic study of 43 cases. Int J Gynecol Pathol.1991;10(2):126-44.

14. Wysocka B, Serkies K, Debniak J, Jassem J, Limon J. Sertoli cell tumor in androgen insensitivity syndrome--a case report. Gynecol Oncol.1999;75(3):480-3.

15. Jarzabek K, Philibert P, Koda M, Sulkowski S, Kotula-Balak M, Bi linska B, et al. Primary amenorrhea in a young Polish woman with complete androgen insensitivity syndrome and SertoliLeydig cell tumor: identification of a new androgen receptor gene mutation and evidence of aromatase hyperactivity and apoptosis dysregulation within the tumor. Gynecol Endocrinol. 2007;23(9):499-504.

16. Ozulker T, Ozpacaci T, Ozulker F, Ozekici U, Bilgic R, Mert M. Incidental detection of Sertoli-Leydig cell tumor by FDG PET/CT imaging in a patient with androgen insensitivity syndrome. Ann Nucl Med. 2010;24(1):35-9.

17. Connell MJ, Ramsey HE, Whang-Peng J, Wiernik PH. Testicular feminization syndrome in three sibs: emphasis on gonadal neoplasia. Am J Med Sci. 1973;265(4):321-33.

18. Damjanov I, Nesbitt KA, Reardon MP, Vidone RA. Giant sertoli cell adenoma in testicular feminization syndrome. Obstet Gynecol. 1976;48(5):624-7.

19. Ramaswamy G, Jagadha V, Tchertkoff V. A testicular tumor resembling the sex cord with annular tubules in a case of the androgen insensitivity syndrome. Cancer. 1985;55(7):1607-11.

20. Ko HM, Chung JH, Lee JH, Jung IS, Choi IS, Juhng SW, et al. Androgen receptor gene mutation associated with complete androgen insensitivity syndrome and Sertoli cell adenoma. Int J Gynecol Pathol. 2001;20(2):196-9.

21. Fleckenstein GH, Gunawan B, Brinck U, Wuttke W, Emons G. Si- 
multaneous sertoli cell tumor and adenocarcinoma of the tunica vaginalis testis in a patient with testicular feminization. Gynecol Oncol. 2002;84(3):460-3.

22. Min-Sung C, So-Young J, Sang-Mo P, Dong-Wha L. A Sertoli-Leydig Cell Tumor in a Patient with Complete Androgen Insensitivity Syndrome-A Case Report. Korean J Pathol. 2007;41:59-62.

23. Scully RE, Galdabini JJ, McNeely BU. Case records of the Massachusetts General Hospital (Case 8-1977). N Engl J Med. 1977;296(8):439-44.

24. Knoke I, Jakubiczka S, Ottersen T, Goppinger A, Wieacker P. A(870) E mutation of the androgen receptor gene in a patient with complete androgen insensitivity syndrome and Sertoli cell tumor. Cancer Genet Cytogenet. 1997;98(2):139-41.

25. Lentz SS, Cappellari JO. Postmenopausal diagnosis of testicular feminization. Am J Obstet Gynecol. 1998;179(1):268-9.

26. Detre Z, Bujdoso G. Testicular feminization syndrome with Ser- toli cell adenoma. Pathol Res Pract. 1984;178(4):403-6.

27. Lin MH, Shamszadeh M, Pitukcheewanont P. Sertoli cell tumor and intratubular germ cell neoplasia located in separate gonads in an adolescent patient with complete androgen insensitivity: a case report and review of literature. J Pediatr Endocrinol Metab. 2012;25(5-6):547-51.

28. Hannema SE, Scott IS, Rajpert-De Meyts E, Skakkebaek NE, Coleman N, Hughes IA. Testicular development in the complete androgen insensitivity syndrome.J Pathol. 2006;208(4):518-27.

29. Ayhan A, Tuncer ZS, Hakverdi AU, Yuce K, Ayhan A. Sertoli-Leydig cell tumor of the ovary: a clinicopathologic study of 10 cases. Eur J Gynaecol Oncol. 1996;17(1):75-8.

30. Choong CS, Fuller PJ, Chu S, Jeske Y, Bowling F, Brown R, et al. Sertoli-Leydig cell tumor of the ovary, a rare cause of precocious puberty in a 12-month-old infant. J Clin Endocrinol Metab. 2002;87(1):49-56. 